\title{
Synthesis, Molecular Docking, MEP and SAR Analysis, ADME-Tox Predictions, and Antimicrobial Evaluation of Novel Mono- and Tetra-Alkylated Pyrazole and Triazole Ligands
}

\author{
Y.Kaddouri $\left(\mathbb{D},{ }^{1}\right.$ B. Bouchal, ${ }^{2}$ F. Abrigach $\left(\mathbb{D},{ }^{1}\right.$ M. El Kodadi $(\mathbb{D}),{ }^{3}$ M. Bellaoui $\left(\mathbb{D},{ }^{2}\right.$ and R. Touzani (iD ${ }^{1}$ \\ ${ }^{1}$ Laboratory of Applied Chemistry \& Environment, Faculty of Sciences, University Mohammed Premier, Oujda 60000, Morocco \\ ${ }^{2}$ Genetics Unit, Medical Sciences Research Laboratory, Faculty of Medicine and Pharmacy of Oujda, \\ University Mohammed Premier, Oujda 60000, Morocco \\ ${ }^{3}$ Laboratoire D'Innovation en Sciences, Technologie et Education (LISTE),CRMEF Oriental, Oujda 60000, Morocco
}

Correspondence should be addressed to Y. Kaddouri; yassine.kaddouri92@gmail.com and M. Bellaoui; bmbellaoui@gmail.com Received 29 October 2020; Revised 27 January 2021; Accepted 11 February 2021; Published 24 February 2021

Academic Editor: Liviu Mitu

Copyright (C) 2021 Y. Kaddouri et al. This is an open access article distributed under the Creative Commons Attribution License, which permits unrestricted use, distribution, and reproduction in any medium, provided the original work is properly cited.

Newly synthesized compounds of $\mathrm{N}$-alkylated heterocyclic compounds were prepared by condensation of amine with alcohol which undergoes a reaction of SN2. These newly synthesized derivatives were characterized by spectral analysis. The objective is to prepare new potent nontoxic antimicrobial agents which are easy to synthesize and could be scaled up in pharmaceutical industries. Thirteen new heterocyclic compounds containing a pyrazole moiety were synthesized with good yields (29.79 to $99.6 \%)$ and were characterized by FTIR, ${ }^{1} \mathrm{H}$ NMR, ${ }^{13} \mathrm{C}$ NMR, and CG-MS techniques. The compounds were divided into two series-monoalkylated compounds (1-11) and tetra-alkylated compounds (12 and 13)-and then evaluated for their in vitro antifungal and antibacterial activities against several fungal and bacterial strains. None of the monoalkylated compounds had antibacterial or antifungal activity. However, the two tetra-alkylated pyrazole ligands displayed strong antibacterial potential. Moreover, compound 12 was more potent against all tested bacterial strains than compound 13. Interestingly, compounds 12 and 13 acted as weak antifungal agents against Saccharomyces cerevisiae. ADME-Tox studies suggested that compounds 12 and 13 exhibit better toxicity profiles than the commercial antibiotic streptomycin. MEP studies suggested that compounds $\mathbf{1 2}$ and $\mathbf{1 3}$ have the same charge locations but differ in their values which are due to the condensed geometry of compound $\mathbf{1 3}$ that make it more polarizable than compound 12. Of particular interest, these different MEPs were evident in ligand protein docking, suggesting that compound $\mathbf{1 2}$ has better affinity with MGL enzyme than compound $\mathbf{1 3}$. All these findings suggested that these novel compounds represent promising antibacterial lead compounds.

\section{Introduction}

According to the World Health Organization, microbial infections are the main threat in the world's deadly diseases, especially in developing countries [1]. Heterocyclic moieties are important building blocks for various interesting compounds used in many fields such as medicine [2], agriculture, and industries [3]. Currently, resistance to firstline antibiotic agents is a severe problem [4]. Infections caused by resistant microbes fail to respond to treatment resulting in prolonged illness and greater risk of death [5]. Among those bacteria, Listeria monocytogenes is a Gram- positive bacterium responsible for invasive listeriosis $[6,7]$ which typically affects old people, pregnant women, neonates, and immunosuppressed individuals, causing gastroenteritis with diarrhea, vomiting, fever, meningitis, encephalitis, miscarriage, and stillbirth [8-10]. Staphylococcus aureus causes bacteremia, infective endocarditis (IE), osteoarticular-, skin-, soft tissue-, pleuropulmonary-, and device-related infections with $30 \%$ human population colonized [11]. Otherwise, Gram-negative Escherichia coli causes septicemia and meningitis in neonates, diarrhea and urinary tract infections, and also hemolytic uremic syndrome [12]. Citrobacter freundii causes infections in urinary 
tract, liver, biliary tract, peritoneum, intestines, bone, respiratory tract, endocardium, wounds, soft tissue, meninges, and bloodstream [13]. Fungal infections caused by Saccharomyces cerevisiae are fungemia, pneumonia, empyema, liver abscess, peritonitis, and vaginitis [14], whereas Candida species cause the commonly known candidiasis [15] and bloodstream infections [16].

In context of fighting against these diseases, nitrogenous compounds have big interest either as antibacterial and/or antifungal agents. Particularly, pyrazole, triazole, benzotriazole, thiazole, imidazole, pyridine, and pyrimidine are very important moieties for the preparation of multiple interesting ligands [17-20].

In objective to look for nontoxic small molecules as new antimicrobial agents, mono- and tetra-N-alkylated heterocyclic derivatives based on pyrazole cores were prepared, characterized, and then evaluated for their in vitro antibacterial and antifungal potential. Additionally, molecular electrostatic potential (MEP) as well as molecular docking investigations was performed on the most active compounds to rationalize the antibacterial results obtained.

\section{Experimental}

All the chemicals were of analytical grades (Sigma-Aldrich, purity $>99 \%$ ), and the melting points were measured on Koffler bank, and FTIR analysis was performed using the FTIR-8400S spectrometer using $\mathrm{KBr}$ pellets. ${ }^{1} \mathrm{H}$ and ${ }^{13} \mathrm{C}$ NMR spectra were recorded on Bruker Avance 300, 400, and $500 \mathrm{MHz}$ using TMS as internal standard in deuterated solvents such as $\mathrm{CDCl}_{3}, \mathrm{CD}_{3} \mathrm{OD}, \mathrm{DMSO}-\mathrm{d}_{6}$, and $\mathrm{CD}_{2} \mathrm{Cl}_{2}$.

\subsection{Chemistry}

2.1.1. General Procedure for Synthesis of Mono- and TetraAlkylated Pyrazole and Triazole ligands. The title compounds (1-13) (Figure 1) were synthesized in one-pot condensation reaction following the known methodology described in literature [17-22].

Compounds 1, 2, and 6-9 were recrystallized from diethyl ether, compounds 3-5, 12, and 13 were recrystallized from DMSO/water $(1: 10)$, while compounds $\mathbf{1 0}$ and 11 were purified using a DCM/water $(3: 1)$ mixture. The structures of all the target compounds (1-13) were established on the basis of FTIR, ${ }^{1} \mathrm{H}$ NMR, ${ }^{13} \mathrm{C}$ NMR, and CG-MS.

Synthesis of N-((3,5-dimethyl-1H-pyrazol-1-yl)methyl) pyridin-2-amine (1) $89.85 \%$ yield, m.p. $136-138^{\circ} \mathrm{C}$; FTIR $\left(\mathbf{K B r}, \boldsymbol{v}\left(\mathbf{c m}^{-\mathbf{1}}\right)\right)$ : $3288(\mathrm{~N}-\mathrm{H}) ; 2950(\mathrm{C}-\mathrm{H}) ; 1614(\mathrm{C}=\mathrm{C}) ; 1532$ (C-C); $1386(\mathrm{C}-\mathrm{N}) ; 1269(\mathrm{C}=\mathrm{N}) ; 1107(\mathrm{~N}-\mathrm{N}) ; 772$ (=C-H); ${ }^{1} \mathrm{H}$ NMR $\left(\mathrm{CDCl}_{3}, 500 \mathrm{MHz}\right) \boldsymbol{\delta}$ ppm: $8.03(\mathrm{~d}, \mathrm{~J}=5 \mathrm{~Hz}, 1 \mathrm{H})$; $7.33(\mathrm{dd}, \mathrm{J}=5 \mathrm{~Hz}, 1 \mathrm{H}) ; 6.56(\mathrm{~d}, \mathrm{~J}=5 \mathrm{~Hz}, 1 \mathrm{H}) ; 6.47$ (dd, $\mathrm{J}=5 \mathrm{~Hz}, 1 \mathrm{H}) ; 5.68(\mathrm{~s}, 1 \mathrm{H}) ; 5.47(\mathrm{t}, \mathrm{J}=5 \mathrm{~Hz}, 1 \mathrm{H}) ; 5.52(\mathrm{~s}$, $2 \mathrm{H}) ; 2.34(\mathrm{~s}, 3 \mathrm{H}) ; 2.13(\mathrm{~s}, 3 \mathrm{H}) ;{ }^{13} \mathrm{C} \mathbf{N M R}\left(\mathbf{C D C l}_{3}\right.$, $125 \mathrm{MHz}) \delta$ ppm: 156.53, 147.39, 137.59, 114.31, 109.06, 106.29, 54.42, 13.49, 11.12, MS found: $\mathrm{m} / \mathrm{z} 281.2$ for $\left[\mathrm{M}+\mathrm{DMSO}^{+}\right.$peak and calculated for $\mathrm{C}_{11} \mathrm{H}_{14} \mathrm{~N}_{4}$ is 202.26.

Synthesis of N-((3,5-dimethyl-1H-pyrazol-1-yl)methyl)6-methylpyridin-2-amine (2): $30 \%$ yield, m.p. $136-138^{\circ} \mathrm{C}$; FTIR (KBr, $\left.\boldsymbol{v}\left(\mathbf{c m}^{-1}\right)\right)$ : $3283(\mathrm{~N}-\mathrm{H}) ; 2880(\mathrm{C}-\mathrm{H}) ; 1607$
$(\mathrm{C}=\mathrm{C}) ; 1537$ (C-C); $1336(\mathrm{C}-\mathrm{N}) ; 1291(\mathrm{C}=\mathrm{N}) ; 1107(\mathrm{~N}-\mathrm{N})$; $782(=\mathrm{C}-\mathrm{H}) ;{ }^{1} \mathbf{H}$ NMR $\left(\mathrm{CD}_{2} \mathbf{C l}_{2}, \mathbf{5 0 0} \mathbf{M H z}\right) \delta$ ppm: $7.21(\mathrm{dd}$, $\mathrm{J}=10 \mathrm{~Hz}, 1 \mathrm{H}) ; 6.40(\mathrm{~d}, \mathrm{~J}=5 \mathrm{~Hz}, 1 \mathrm{H}) ; 6.25(\mathrm{~d}, \mathrm{~J}=10 \mathrm{~Hz}, 1 \mathrm{H})$; 5.64 (s, $1 \mathrm{H}) ; 5.43$ (s, $2 \mathrm{H}) ; 2.36$ (s, $3 \mathrm{H}) ; 2.27$ (s, $3 \mathrm{H}) ; 2.06$ (s, $3 \mathrm{H}) ;{ }^{13} \mathrm{C}$ NMR $\left(\mathrm{CD}_{2} \mathrm{Cl}_{2}, \mathbf{1 2 5} \mathbf{M H z}\right) \delta$ ppm: 157.01, 155.95, $146.57,139.51,137.98,112.49,105.95,104.97,53.79,24.39$, 13.78, 11.17, MS found: $\mathrm{m} / \mathrm{z} 281.2$ for $\left[\mathrm{M}+\mathrm{NH}_{4} \mathrm{Cl}\right]^{+}$peak and calculated for $\mathrm{C}_{12} \mathrm{H}_{16} \mathrm{~N}_{4}$ is 216.29 .

Synthesis of N-((1H-1,2,4-triazol-1-yl)methyl)-5-bromopyridin-2-amine (3): $62.14 \%$ yield, m.p. $64-66^{\circ} \mathrm{C} ;{ }^{1} \mathbf{H}$ NMR (DMSO-d 6 , $500 \mathrm{MHz}$ ) $\boldsymbol{\delta}$ ppm: $8.56(\mathrm{~s}, 1 \mathrm{H}) ; 8.06$ (s, $1 \mathrm{H}) ; 7.93$ $(\mathrm{s}, 1 \mathrm{H}) ; 7.67(\mathrm{t}, \mathrm{J}=6.9 \mathrm{~Hz}, 1 \mathrm{H}) ; 7.63(\mathrm{~d}, \mathrm{~J}=8.9 \mathrm{~Hz}, 1 \mathrm{H}) ; 6.62(\mathrm{~d}$, $J=7.5 \mathrm{~Hz}, 1 \mathrm{H}) ; 5.67$ (s, $2 \mathrm{H}) .{ }^{13} \mathrm{C}$ NMR (DMSO-d $6.125 \mathrm{MHz}$ ) $\delta$ ppm: $\delta 155.68,151.11,147.63,144.07,111.06,107.64,54.55$, MS found: $\mathrm{m} / z 370.9$ for $\left[\mathrm{M}+2 \mathrm{ACN}+\mathrm{NH}_{4}\right]+$ peak and calculated for $\mathrm{C}_{8} \mathrm{H}_{8} \mathrm{BrN}_{5}$ is 254.09 .

Synthesis of N-((1H-pyrazol-1-yl)methyl)-5-bromopyridin-2-amine (4): $62.36 \%$ yield, m.p. $114-116^{\circ} \mathrm{C}$; FTIR (KBr, $\left.\boldsymbol{v}\left(\mathrm{cm}^{-1}\right)\right): 3290(\mathrm{NH}) ; 2945(\mathrm{CH}$ alkene); $1541(\mathrm{C}=\mathrm{C}) ; 1491$ (C-C); 1260 (C=N); 1217 (C-N); 960 (C-C); 756 (=C-H); ${ }^{1} \mathbf{H}$ NMR (DMSO-d 6 , 500 MHz) $\boldsymbol{\delta}$ ppm: $8.15(\mathrm{~s}, 2 \mathrm{H}) ; 7.98(\mathrm{t}$, $\mathrm{J}=6.9 \mathrm{~Hz}, 1 \mathrm{H}) ; 7.62(\mathrm{~d}, \mathrm{~J}=8.6 \mathrm{~Hz}, 1 \mathrm{H}) ; 7.45(\mathrm{~s}, 1 \mathrm{H}) ; 6.64(\mathrm{~d}$, $\mathrm{J}=8.9 \mathrm{~Hz}, 1 \mathrm{H}) ; 6.22(\mathrm{~s}, 1 \mathrm{H}) ; 5.59(\mathrm{~s}, 2 \mathrm{H}) .{ }^{13} \mathrm{C} \mathbf{N M R}$ (DMSO-d $6125 \mathrm{MHz}$ ) $\delta$ ppm: 156.11, 147.63, 139.62, $138.55,129.47,110.78,107.16,106.16,56.44$, MS found: $\mathrm{m} / z$ 372.8 for $[\mathrm{M}+\mathrm{DMSO}+\mathrm{K}+2 \mathrm{H}]^{+}$peak and calculated for $\mathrm{C}_{9} \mathrm{H}_{9} \mathrm{BrN}_{4}$ is 253.10 .

Synthesis of 5-bromo-N-((3,5-dimethyl-1H-pyrazol-1yl)methyl)pyridin-2-amine (5): $93.6 \%$ yield, m.p. 150-152 ${ }^{\circ}$ C; FTIR (KBr, $\left.v\left(\mathbf{c m}^{-1}\right)\right)$ : $3430(\mathrm{NH}) ; 3260-2922$ (CH); $1573(\mathrm{C}=\mathrm{N}) ; 1512(\mathrm{C}=\mathrm{C}) ; 1355$ (C-N benzene); 1289 (C-N alkyl); 619 (C-Br); ${ }^{1}$ H NMR (DMSO-d 6 , 500 MHz) $\delta$ ppm: $8.11(\mathrm{~s}, 1 \mathrm{H}) ; 7.84(\mathrm{t}, \mathrm{J}=8.6 \mathrm{~Hz}, 1 \mathrm{H}) ; 7.62(\mathrm{~d}, \mathrm{~J}=8.5 \mathrm{~Hz}$, $1 \mathrm{H}) ; 6.63(\mathrm{~d}, \mathrm{~J}=7.5 \mathrm{~Hz}, 1 \mathrm{H}) ; 5.76(\mathrm{~d}, \mathrm{~J}=8.9 \mathrm{~Hz}, 2 \mathrm{H}) ; 2.56(\mathrm{~s}$, $3 \mathrm{H}) ; 2.35$ (s, $3 \mathrm{H}) .{ }^{13} \mathrm{C}$ NMR (DMSO-d6, $\left.125 \mathrm{MHz}\right) \delta$ ppm: $156.06,147.44,146.16,144.07,110.66,104.75,53.42$, MS found: $\mathrm{m} / \mathrm{z} 213$ for $\left[\mathrm{M}+\mathrm{CH}_{3} \mathrm{OH}\right]^{+}$peak and calculated for $\mathrm{C}_{11} \mathrm{H}_{13} \mathrm{BrN}_{4}$ is 281.16 .

Synthesis of N-((1H-pyrazol-1-yl)methyl)thiazol-2amine (6): $53.08 \%$ yield, m.p. $108-110^{\circ} \mathrm{C}$; FTIR $\left(\mathrm{KBr}, \boldsymbol{v}\left(\mathrm{cm}^{-}\right.\right.$ $\left.\left.{ }^{1}\right)\right)$ : 3239 (N-H); 3020 (C-H); 1560 (C=C); 1540 (C-C); 1386 (C-N); 1159 (C=N); $1050(\mathrm{~N}-\mathrm{N}) ; 757$ (=C-H); $700(\mathrm{C}-\mathrm{S}) .{ }^{\mathbf{1}} \mathbf{H}$ NMR (DMSO-d6, 500 MHz) $\delta$ ppm: $8.69(\mathrm{~d}, \mathrm{~J}=5 \mathrm{~Hz}, 1 \mathrm{H})$; $7.80(\mathrm{~d}, \mathrm{~J}=5 \mathrm{~Hz}, 1 \mathrm{H}) ; 7.46(\mathrm{~d}, \mathrm{~J}=5 \mathrm{~Hz}, 1 \mathrm{H}) ; 7.09$ (d, J = $5 \mathrm{~Hz}$, $1 \mathrm{H}) ; 6.74(\mathrm{dd}, \mathrm{J}=5 \mathrm{~Hz}, 1 \mathrm{H}) ; 6.23(\mathrm{t}, \mathrm{J}=5 \mathrm{~Hz}, 1 \mathrm{H}) ; 5.56(\mathrm{~s}$, $2 \mathrm{H}$ ); ${ }^{13} \mathrm{C}$ NMR (DMSO-d6, $\left.125 \mathrm{MHz}\right) \delta$ ppm: 58.93, $105.27,108.02,129.94,138.47,138.83$, MS found: $\mathrm{m} / \mathrm{z} 213$ for $\left[\mathrm{M}+\mathrm{CH}_{3} \mathrm{OH}\right]^{+}$peak and calculated for $\mathrm{C}_{7} \mathrm{H}_{8} \mathrm{~N}_{4} \mathrm{~S}$ is 180.23 .

Synthesis of N-((3,5-dimethyl-1H-pyrazol-1-yl)methyl) thiazol-2-amine (7): $37.12 \%$ yield, m.p. $152-154^{\circ} \mathrm{C}$; FTIR $\left(\mathrm{KBr}, \boldsymbol{v}\left(\mathbf{c m}^{-\mathbf{1}}\right)\right)$ : $3209(\mathrm{~N}-\mathrm{H}) ; 2995(\mathrm{C}-\mathrm{H}) ; 2368(\mathrm{C}=\mathrm{N}) ; 1562$ $(\mathrm{C}=\mathrm{C}) ; 1535$ (C-C); $1301(\mathrm{C}-\mathrm{N}) ; 1177(\mathrm{C}=\mathrm{N}) ; 1135(\mathrm{~N}-\mathrm{N})$; 787 (=C-H); $700(\mathrm{C}-\mathrm{S}) .{ }^{\mathbf{1}} \mathbf{H}$ NMR $\left(\mathrm{CDCl}_{3}, 500 \mathrm{MHz}\right) \boldsymbol{\delta}$ ppm: $7.05(\mathrm{~d}, \mathrm{~J}=5 \mathrm{~Hz}, 1 \mathrm{H}) ; 6.43(\mathrm{~d}, \mathrm{~J}=5 \mathrm{~Hz}, 1 \mathrm{H}) ; 5.70(\mathrm{~s}, 1 \mathrm{H})$; 5.45 (s, $2 \mathrm{H}) ; 2.21$ (t, J = 5 Hz, $1 \mathrm{H}) ; 2.13$ (s, $3 \mathrm{H}) ; 2.10$ (s, $3 \mathrm{H})$. ${ }^{13} \mathrm{C} \mathrm{NMR}\left(\mathrm{CDCl}_{3}, 125 \mathrm{MHz}\right) \delta$ ppm: $167.52,148.68,140.07$, 138.67, 108.07, 105.57, 56.74, 13.46, 11.11, MS found: $\mathrm{m} / \mathrm{z}$ 293.1 for $[\mathrm{M}+2 \mathrm{ACN}+\mathrm{H}]^{+}$peak and calculated for $\mathrm{C}_{9} \mathrm{H}_{12} \mathrm{~N}_{4} \mathrm{~S}$ is 208.28 . 
<smiles>[R][Y]1c([R])nn(CNc2nc([R])c([R])c([R])c2[R3])c1[R3]</smiles>

1: $\mathrm{R}_{1}=\mathrm{R}_{2}=\mathrm{R}_{3}=\mathrm{R}_{4}=\mathrm{H} ; \mathrm{R}_{5}=\mathrm{CH}_{3} ; \mathrm{X}=\mathrm{CH}$ 2: $\mathrm{R}_{1}=\mathrm{R}_{5}=\mathrm{CH}_{3} ;=\mathrm{R}_{2}=\mathrm{R}_{3}=\mathrm{R}_{4}=\mathrm{H} ; \mathrm{X}=\mathrm{CH}$ 3: $\mathrm{R}_{1}=\mathrm{R}_{3}=\mathrm{R}_{5}=\mathrm{R}_{4}=\mathrm{H} ; \mathrm{R}_{2}=\mathrm{Br} ; \mathrm{X}=\mathrm{N}$ 4: $\mathrm{R}_{1}=\mathrm{R}_{3}=\mathrm{R}_{5}=\mathrm{R}_{4}=\mathrm{H} ; \mathrm{R}_{2}=\mathrm{Br} ; \mathrm{X}=\mathrm{CH}$ 5: $\mathrm{R}_{1}=\mathrm{R}_{3}=\mathrm{R}_{4}=\mathrm{H} ; \mathrm{R}_{2}=\mathrm{Br} ; \mathrm{R}_{5}=\mathrm{CH}_{3} ; \mathrm{X}=\mathrm{CH}$

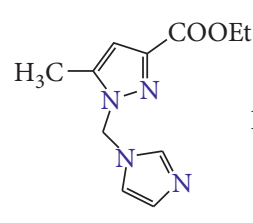

$\underline{9}$
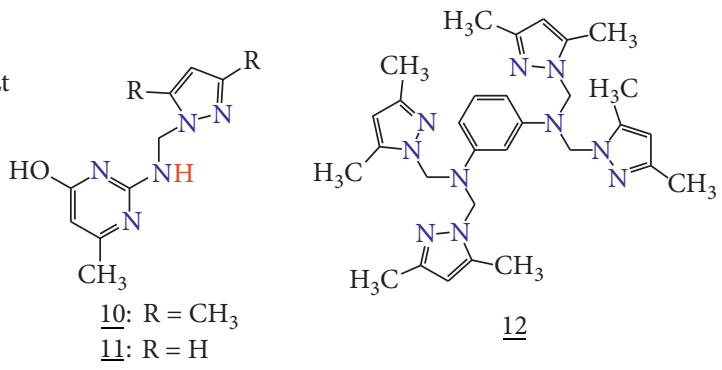
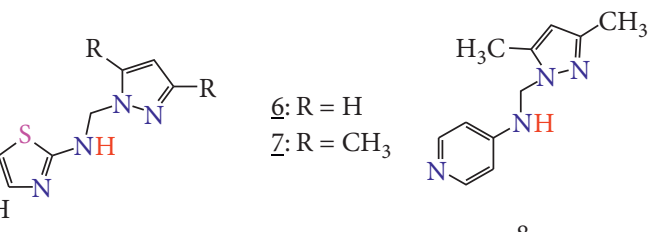

$\underline{8}$

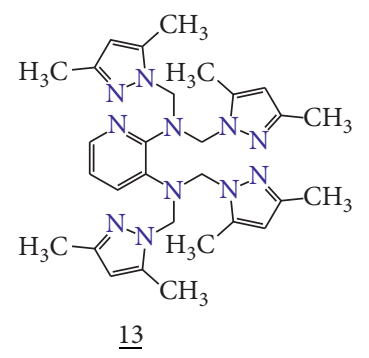

Figure 1: Chemical structure of compounds 1-13 studied in this paper.

Synthesis of N-((3,5-dimethyl-1H-pyrazol-1-yl)methyl) pyridin-4-amine (8): $29.79 \%$ yield: m.p. $154-156^{\circ} \mathrm{C}$; FTIR $\left(\mathrm{KBr}, \boldsymbol{v}\left(\mathrm{cm}^{-1}\right)\right)$ : $3436(\mathrm{~N}-\mathrm{H}) ; 2932(\mathrm{C}-\mathrm{H}) ; 2364(\mathrm{C}=\mathrm{N})$; $1653(\mathrm{C}=\mathrm{C}) ; 1559(\mathrm{C}-\mathrm{C}) ; 1273(\mathrm{C}-\mathrm{N}) ; 1218(\mathrm{C}=\mathrm{N}) ; 986(\mathrm{~N}-$ $\mathrm{N}) ; 824(=\mathrm{C}-\mathrm{H}) .{ }^{1} \mathrm{H}$ NMR $\left(\mathrm{CD}_{\mathbf{3}} \mathrm{OD}, \mathbf{3 0 0} \mathrm{MHz}\right) \boldsymbol{\delta}$ ppm: 8.06 $(\mathrm{d}, \mathrm{J}=8.6 \mathrm{~Hz}, 2 \mathrm{H}) ; 6.81(\mathrm{~d}, \mathrm{~J}=7.5 \mathrm{~Hz}, 2 \mathrm{H}) ; 6.79(\mathrm{t}, \mathrm{J}=8.9 \mathrm{~Hz}$, $1 \mathrm{H}) ; 6.55$ (s, $1 \mathrm{H}) ; 5.39$ (s, $2 \mathrm{H}) ; 2.32$ (s, $3 \mathrm{H}) ; 2.17(\mathrm{~s}, 3 \mathrm{H}) .{ }^{13} \mathrm{C}$ NMR $\left(\mathrm{CD}_{3} \mathrm{OD}, 75 \mathrm{MHz}\right) \delta$ ppm: 155.50, 148.49, 147.45, $139.91,108.89,105.87,65.58,11.91,9.64$, MS found: $\mathrm{m} / z$ 281.4 for $[\mathrm{M}+\mathrm{DMSO}+\mathrm{H}]^{+}$peak and calculated for $\mathrm{C}_{11} \mathrm{H}_{14} \mathrm{~N}_{4}$ is 202.26 .

Synthesis of Ethyl 1-((1H-imidazol-1-yl)methyl)-5methyl-1H-pyrazole-3-carboxylate (9): $99.6 \%$ yield: m.p. 74-76 ${ }^{\circ}$; FTIR $\left(\mathrm{KBr}, \boldsymbol{v}\left(\mathrm{cm}^{-1}\right)\right)$ : $3237(\mathrm{C}=\mathrm{C}-\mathrm{H}) ; 1702(\mathrm{C}=\mathrm{O})$; 1431 (C-C); 1169 (C-O); $1393(\mathrm{C}-\mathrm{N}) ; 1172(\mathrm{C}=\mathrm{N}) ; 1066(\mathrm{~N}-$ N); $754(=\mathrm{C}-\mathrm{H}) .1 \mathrm{H}$ NMR (DMSO-d6, $500 \mathrm{MHz}) \delta$ ppm: $7.67(\mathrm{~s}, 1 \mathrm{H}) ; 7.04(\mathrm{~s}, 2 \mathrm{H}) ; 7.04(\mathrm{~s}, 1 \mathrm{H}) ; 6.50(\mathrm{~s}, 2 \mathrm{H}) ; 4.25$ (q, $\mathrm{J}=7.5 \mathrm{~Hz}, 2 \mathrm{H}) ; 2.59(\mathrm{~s}, 3 \mathrm{H}) ; 1.28(\mathrm{t}, 3 \mathrm{H}) .{ }^{13} \mathrm{C}$ NMR (DMSO-d $6125 \mathrm{MHz}) \delta$ ppm: 161.62, 135.10, 121.63, $106.55,59.88,14.13,10.68$, MS found: $\mathrm{m} / \mathrm{z} 310$ for $\left[\mathrm{M}+\mathrm{ACN}+\mathrm{CH}_{3} \mathrm{OH}+\mathrm{H}\right]^{+}$peak and calculated for $\mathrm{C}_{11} \mathrm{H}_{14} \mathrm{~N}_{4} \mathrm{O}_{2}$ is 234.26 .

Synthesis of 2-(((1H-pyrazol-1-yl)methyl)amino)-6methylpyrimidin-4-ol (10): $93.82 \%$ yield: m.p. $238-240^{\circ} \mathrm{C}$, FTIR $\left(\mathbf{K B r}, \boldsymbol{v}\left(\mathrm{cm}^{-\mathbf{1}}\right)\right)$ : $3398(\mathrm{NH}) ; 3112(\mathrm{OH}) ; 3004(\mathrm{CH}$ alkene); $1640(\mathrm{C}=\mathrm{C}) ; 1500(\mathrm{C}-\mathrm{C}) ; 1304(\mathrm{C}=\mathrm{N}) ; 1194(\mathrm{C}-\mathrm{N})$, 1044 (C-C), 786 (=C-H), ${ }^{1}$ H NMR (DMSO-d6, 500 MHz): $\boldsymbol{\delta}$ $11.3(\mathrm{~s}, 1 \mathrm{H}) ; 6.71$ (s, $1 \mathrm{H}) ; 6.11$ (s, $2 \mathrm{H}) ; 5.18$ (s, $2 \mathrm{H}) ; 1.89$ (s, $3 \mathrm{H}) ; 1.80(\mathrm{~s}, 1 \mathrm{H}) ; 1.76(\mathrm{~s}, 3 \mathrm{H}) ; 1.63(\mathrm{~s}, 3 \mathrm{H}) .{ }^{13} \mathrm{C}$ NMR $($ DMSO-d 6 , 125 MHz) $\delta$ ppm: $164.80(\mathrm{C}-\mathrm{OH}) ; 155.47$ (C$\mathrm{CH} 3) ; 153.96(\mathrm{C}-\mathrm{NH}) ; 138.96$ (CH (3, pyrazole)); 129.30, 105.64, 100.34, 73.24, 23.6, MS found: $\mathrm{m} / \mathrm{z} 234.1$ for $[\mathrm{M}+\mathrm{H}]+$ peak and calculated for $\mathrm{C}_{11} \mathrm{H}_{15} \mathrm{~N}_{5} \mathrm{O}$ is 233.28 .

Synthesis of 2-(((3,5-dimethyl-1H-pyrazol-1-yl)methyl) amino)-6-methylpyrimidin-4-ol (11): $90.65 \%$ yield: m.p. $100-102^{\circ} \mathrm{C}$, FTIR (KBr, $\left.\boldsymbol{v}\left(\mathrm{cm}^{-1}\right)\right): 3386(\mathrm{NH}) ; 3123(\mathrm{OH})$; $2986(\mathrm{CH}$ alkene); $1628(\mathrm{C}=\mathrm{C}) ; 1450(\mathrm{C}-\mathrm{C}) ; 1370(\mathrm{C}=\mathrm{N})$; 1188 (C-N), 1035 (C-C), 794 (=C-H), ${ }^{1}$ H NMR (DMSO-d6, $500 \mathrm{MHz}) \boldsymbol{\delta}$ ppm: $7.34(\mathrm{~s}, 1 \mathrm{H}) ; 6.71(\mathrm{~s}, 1 \mathrm{H}) ; 6.11(\mathrm{~s}, 2 \mathrm{H})$; 5.18 (s, $2 \mathrm{H}) ; 1.89$ (s, $3 \mathrm{H}) ; 1.80$ (s, $1 \mathrm{H}) ; 1.76$ (s, $3 \mathrm{H}) ; 1.63$ (s,
$3 \mathrm{H}) .{ }^{13} \mathrm{C}$ NMR (DMSO-d6, $125 \mathrm{MHz}$ ) $\delta$ ppm: 175.56, $172.05,171.78,163.62,161.41,99.54,25.16,23.20,22.41$, MS found: $\mathrm{m} / z 206.1$ for $[\mathrm{M}+\mathrm{H}]^{+}$peak and calculated for $\mathrm{C}_{9} \mathrm{H}_{11} \mathrm{~N}_{5} \mathrm{O}$ is 205.22 .

Synthesis of $\mathrm{N}_{1}, \mathrm{~N}_{1}, \mathrm{~N}_{3}, \mathrm{~N}_{3}$-tetrakis((3,5-dimethyl-1Hpyrazol-1-yl)methyl)benzene-1,3-diamine (12): 24.2\% yield, m.p. $87-89^{\circ} \mathrm{C}$. FTIR $\left(\mathrm{KBr}, \boldsymbol{v}\left(\mathrm{cm}^{-\mathbf{1}}\right)\right)$ : 3276-2916 (CH); 1548 $(\mathrm{C}=\mathrm{N}) ; 1505 \quad(\mathrm{C}=\mathrm{C}) ; 1337$ (C-N (phenyl)); 1128 (C-N (pyrazole)), ${ }^{\mathbf{1}} \mathrm{H}$ NMR (DMSO-d $\left.\mathbf{6}_{\mathbf{6}}, \mathbf{5 0 0} \mathbf{M H z}\right) \boldsymbol{\delta} \mathbf{~ p p m : ~ 7 , 5 2 ~ ( s , ~}$ $1 \mathrm{H}) ; 7.15$ and $6.80(\mathrm{~s}, 2 \mathrm{H}) ; 6.29(\mathrm{~s}, 4 \mathrm{H}) ; 6.28(\mathrm{~s}, 1 \mathrm{H}) ; 5.88$ (s, $8 \mathrm{H}) ; 3.42(\mathrm{~s}, 12 \mathrm{H}) ; 2.55$ (s, $12 \mathrm{H}),{ }^{13}$ C NMR (DMSO-d 6 , $125 \mathrm{MHz}) \delta$ ppm: 129.66, 118.93, 115.73, 105.57, 66.14.

Synthesis of $\mathrm{N}_{2}, \mathrm{~N}_{2}, \mathrm{~N}_{3}, \mathrm{~N}_{3}$-tetrakis((3,5-dimethyl-1Hpyrazol-1-yl)methyl)pyridine-2,3-diamine (13): $\quad 73.91 \%$ yield, m.p. $116-118^{\circ} \mathrm{C}$, FTIR $\left(\mathbf{K B r}, \boldsymbol{v}\left(\mathbf{c m}^{-\mathbf{1}}\right)\right): 3000(=\mathrm{C}-\mathrm{H})$; 2363 (C-H); 1555 (C=C); 1532 (C-C); 1396 (C-N); 1304 $(\mathrm{C}=\mathrm{N}) ; 1132(\mathrm{~N}-\mathrm{N}) ; 782(=\mathrm{C}-\mathrm{H}) .{ }^{1} \mathbf{H}$ NMR $\left(\mathbf{C D}_{2} \mathbf{C l}_{2}\right.$, $500 \mathrm{MHz}) \delta$ ppm: $7.22(\mathrm{~d}, \mathrm{~J}=5 \mathrm{~Hz}, 1 \mathrm{H}) ; 7.11(\mathrm{~s}, 1 \mathrm{H}) ; 6.71$ $(\mathrm{d}, \mathrm{J}=5 \mathrm{~Hz}, 1 \mathrm{H}) ; 5.89(\mathrm{dd}, \mathrm{J}=15 \mathrm{~Hz}, 1 \mathrm{H}) ; 5.51(\mathrm{~s}, 8 \mathrm{H}) ; 2.35$ $(\mathrm{s}, 12 \mathrm{H}) ; 2.20(\mathrm{~s}, 12 \mathrm{H}) .{ }^{13} \mathrm{C}$ NMR $\left(\mathrm{CD}_{2} \mathrm{Cl}_{2}, \mathbf{1 2 5} \mathrm{MHz}\right) \boldsymbol{\delta}$ ppm: 149.11, 148.42, 140.09, 138.99, 109.53, 107.94, 105.13, $70.45,56.48,13.14,10.82$.

\subsection{Antimicrobial Activity}

2.2.1. Determination of the Antibacterial Activity. The antibacterial effect was evaluated using the broth macrodilution method with phenol red indicator [23] against two Gram-negative bacterial strains, Escherichia coli and Citrobacter freundii, and two Gram-positive bacterial strains, Staphylococcus aureus and Listeria monocytogenes.

The bacterial isolate was cultivated overnight in liquid Luria-Bertani medium (LB) at $37^{\circ} \mathrm{C}$ under aeration. After that, a suspension containing $106 \mathrm{CFU} / \mathrm{mL}$ of bacterial cells was prepared. Then, $250 \mu \mathrm{L}$ of this bacterial suspension was used to inoculate test tubes containing phenol red medium and the compound to be tested. After 24 hours of incubation at $37^{\circ} \mathrm{C}$, bacterial growth was determined by a change of the colour of phenol red indicator from red to yellow. In the presence of antibacterial activity, the phenol red indicator 
remains red. While in the absence of antibacterial activity, the colour of the culture becomes yellow following the acidification of the medium due to bacterial growth. The compounds have been tested at $500 \mu \mathrm{M}$, and all experiments were repeated three times for each drug.

\subsubsection{Determination of the Minimum Inhibitory Concen-} tration (MIC). Cultures were performed in the presence of phenol red indicator using different concentrations of the active compound. Bacterial growth was determined by visual observation of the red colour indicator as described above. We defined the MIC as the lowest drug concentration that inhibits bacterial growth after incubation at $37^{\circ} \mathrm{C}$ for 24 hours. All experiments were carried out in triplicate, and means were calculated.

2.2.3. Determination of the Minimum Bactericidal Concentration $(M B C)$. The $\mathrm{MBC}$ is the lowest drug concentration that kills $99 \%$ of bacteria after $24 \mathrm{~h}$ of incubation. MBCs were determined as described in [24, 25].

2.2.4. Determination of the Antifungal Activity. Liquid cell culture method was used for the evaluation of the antifungal activity of the studied compounds against two fungal strains: Candida glabrata and Saccharomyces cerevisiae. The absorbance of the cells at $600 \mathrm{~nm}\left(\mathrm{OD}_{600}\right)$ was measured to monitor the growth rate of fungal cells in liquid culture using a V-1200 spectrophotometer (Shanghai Mapada Instruments Co., Ltd.). With this spectrophotometer, the reading is proportional to the cell number for an $\mathrm{OD}_{600}<2.5$. Therefore, when culture was very overgrown, the $\mathrm{OD}_{600}$ measurement was carried out after dilution of the culture, and then the dilution factor was used to calculate the OD in the original culture. The methodology used for the determination of the antifungal activity of a compound is as follows: firstly, cells were grown overnight in yeast peptone dextrose medium (YPD) at $30^{\circ} \mathrm{C}$ in a shaking incubator. Then, cells were diluted from the overnight culture to an $\mathrm{OD}_{600}$ of $\sim 0.08$ and allowed to grow until the $\mathrm{OD}_{600}$ reached $\sim 0.14$, to ensure that the cells were in the logarithmic phase. The compound was then added, and the growth rate of fungal cells was determined every two hours by measuring $\mathrm{OD}_{600}$. All compounds were diluted in DMSO, and all assays, including the "no drug" control, contained 1\% DMSO. Optical density $\left(\mathrm{OD}_{600}\right)$ was measured every $2 \mathrm{~h}$ to follow cell growth. All experiments were carried out in triplicate, and the curves shown are an average of three experiments. Error bars are presented, and where they are not visible, they are smaller than the data symbols. All experiments were repeated three times, and means were calculated.

2.3. DFT Study: MEP Surfaces. The chemical structures of the studied molecules were sketched using GaussView 6.0 and then optimized by the DFT/B3LYP method with 6-31G (d,p) basis sets using Gaussian 09W software [26].
2.4. ADME-Tox Predictions. In silico prediction of the ADME properties (absorption, distribution, metabolism, and excretion) and the toxicity risks (mutagenicity, tumorigenicity, irritation, and reproduction) was performed using SwissADME web tool (http://www.swissadme.ch).

2.5. Molecular Docking Study. The biological target selected for this study is the crystal structure of L-methionine $\gamma$-lyase from Citrobacter freundii in complex with norleucine (PDB: 3JWB). Actually, methionine $\gamma$-lyase (MGL) is an essential enzyme involved in the catalytic reaction of $\gamma$-elimination and $\gamma$-substitution of L-methionine and its derivatives, which play important roles in several biological processes. The presence of this enzyme in many bacteria including pathogenic ones and its absence in human (generally in mammals) makes it a potential target to design novel antibacterial drugs.

Figure 2 displays the 3D structure of this enzyme and its active pocket. The docking study was carried out utilizing Molecular Operating Environment (MOE) 2015.10) software.

\section{Results and Discussion}

3.1. Chemistry. As an example, for details of the characterization of compound 13, where the ${ }^{1} \mathrm{H}$ NMR $\left(\mathrm{CD}_{2} \mathrm{Cl}_{2}\right.$, $500 \mathrm{MHz})$ spectrum (Figure 3$)$ of $\mathrm{N}^{2}, \mathrm{~N}^{2}, \mathrm{~N}^{3}, \mathrm{~N}^{3}$-tetrakis $((3,5-$ dimethyl-1H-pyrazol-1-yl)methyl)pyridine-2,3-diamine

(13) contains the following peaks:

(i) Doublet peak at 7.13 for proton of $\mathbf{C H}$ (1)

(ii) Doublet peak at 6.57 for the proton $\mathbf{C H}$ (3)

(iii) Doublet bidoublet peak at 6.06 for the proton of $\mathbf{C H}$ (2)

(iv) Singlet peak at 5.89 and 5.80 for the proton of $\mathbf{C H}$ $\left(4^{\prime}\right)$ on the pyrazole ring

(v) Singlet peak at 5.51 and 5.42 for the protons of $\mathbf{C H}_{2}$ )

(vi) Singlet peak at 2.45 for the protons of $\mathbf{C H}_{3}(\mathbf{a}, \mathbf{b})$

The ${ }^{13} \mathrm{CNMR}\left(\mathrm{CD}_{2} \mathrm{Cl}_{2}, 125 \mathrm{MHz}\right)$ spectrum (Figure 4$)$ of $\mathrm{N}^{2}, \mathrm{~N}^{2}, \mathrm{~N}^{3}, \mathrm{~N}^{3}$-tetrakis((3,5-dimethyl-1H-pyrazol-1-yl) methyl)pyridine-2,3-diamine (13) contain the following peaks at 140.09 for carbon C1; 138.68 for carbon C4 and C5'; 148.42 and 138.99 for carbon C3'; 109.53 for carbon C2; 107.94 for carbon C3; 105.89, 105.13, and 105.05 for carbon C4'; 56.48 for carbon $\mathbf{C H}_{2}$; and $13.14,10.82$, and 10.37 for carbon $\mathbf{C H}_{3}$.

3.2. Antimicrobial Activity. The antibacterial potential of the synthesized mono- and tetra-alkylated pyrazole and triazole derivatives shown in Figure 1 was evaluated against four bacterial strains (two Gram-positive, Staphylococcus aureus and Listeria monocytogenes, and two Gram-negative Escherichia coli and Citrobacter freundii). All the compounds were tested at $500 \mu \mathrm{M}$ as described in Section 2.2.1. As shown in Table 1, all the screened monodentate ligands displayed no antimicrobial effect against all used strains. This result could be explained by the fact that these compounds lack 


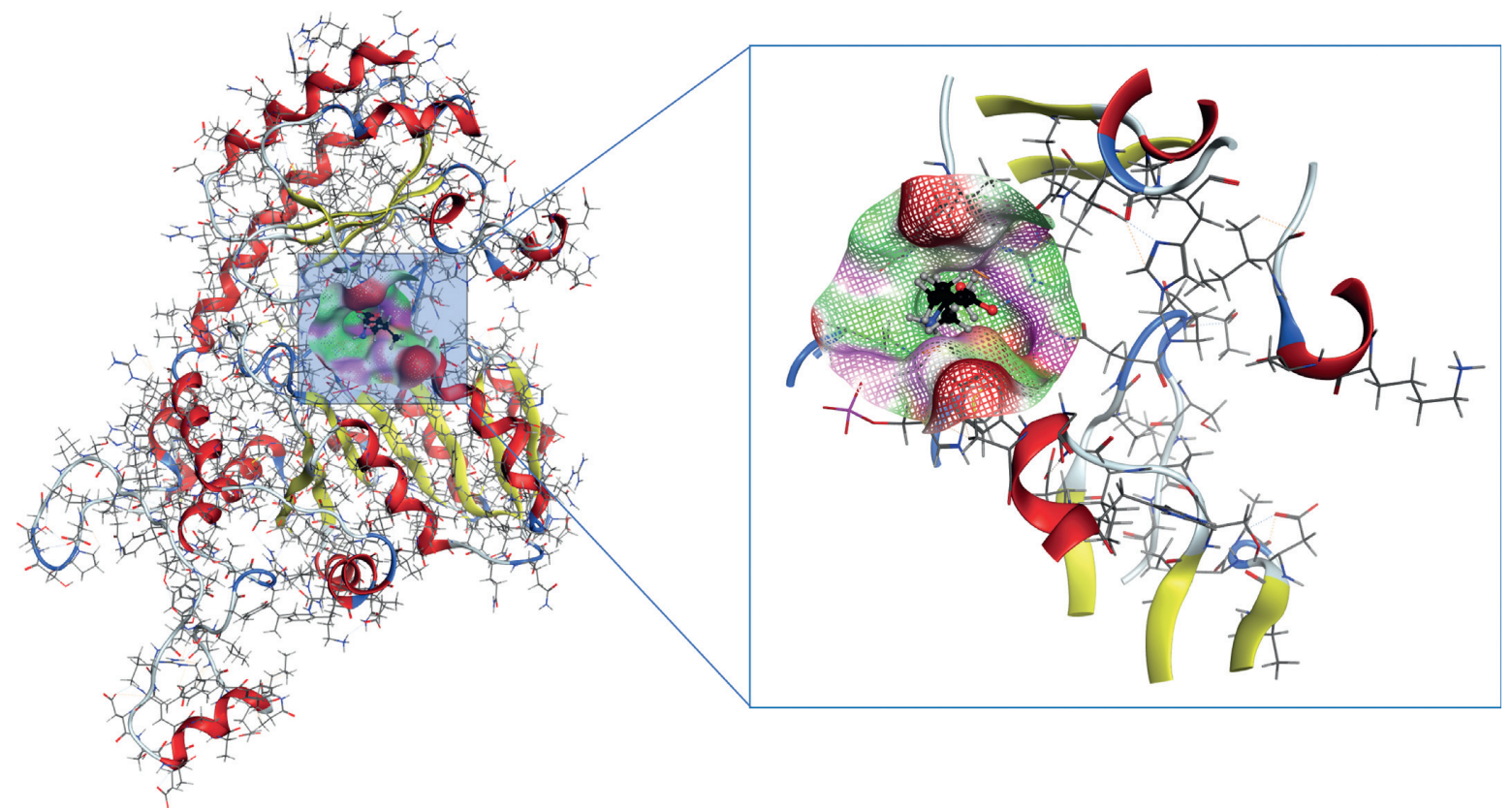

FIgURE 2: The 3D structure of L-methionine $\gamma$-lyase enzyme and the chosen active site for C. freundii (PDB: 3JWB).

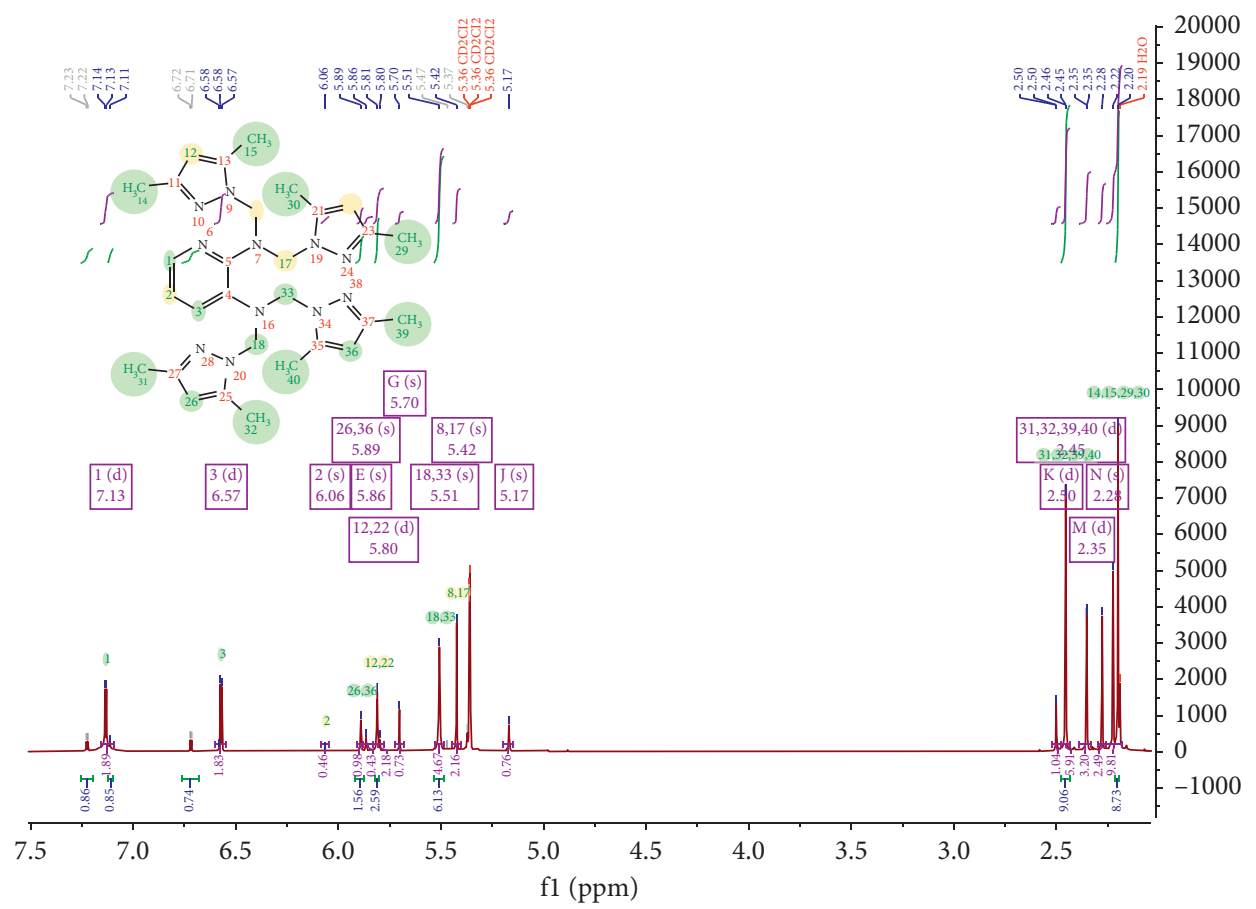

Figure 3: ${ }^{1} \mathrm{H}$ NMR spectrum of $\mathrm{N}_{2}, \mathrm{~N}_{2}, \mathrm{~N}_{3}, \mathrm{~N}_{3}$-tetrakis((3,5-dimethyl-1H-pyrazol-1-yl) methyl)pyridine-2,3-diamine (13).

pharmacophore sites which can act by inhibiting bacterial growth.

The compounds have been tested at $500 \mu \mathrm{M}$. All experiments were repeated three times, and the result obtained for each time is presented. --- indicates no inhibition of bacterial growth, and +++ indicates inhibition of bacterial growth.

In contrast, the two tetra-alkylated derivatives exhibit potent antibacterial activity against all the studied strains
(Table 2). Therefore, MIC and MBC of these compounds were determined as described in Sections 2.2.2 and 2.2.3. The $\mathrm{MIC}$ and MBC of compound $\mathbf{1 2}$ against L. monocytogenes, E. coli, and $S$. aureus were $300 \mu \mathrm{M}$. Interestingly, this compound was much more active against $C$. freundii with an MIC of $100 \mu \mathrm{M}$ and MBC of $200 \mu \mathrm{M}$ (Table 2). Similarly, C. freundii was the most sensitive to compound $\mathbf{1 3}$ $(\mathrm{MIC}=300 \mu \mathrm{M}, \mathrm{MBC}=400 \mu \mathrm{M})$, followed by $S$. aureus $(\mathrm{MIC}=400 \mu \mathrm{M}, \mathrm{MBC}=500 \mu \mathrm{M})$, E. coli $(\mathrm{MIC}=500 \mu \mathrm{M}$, 


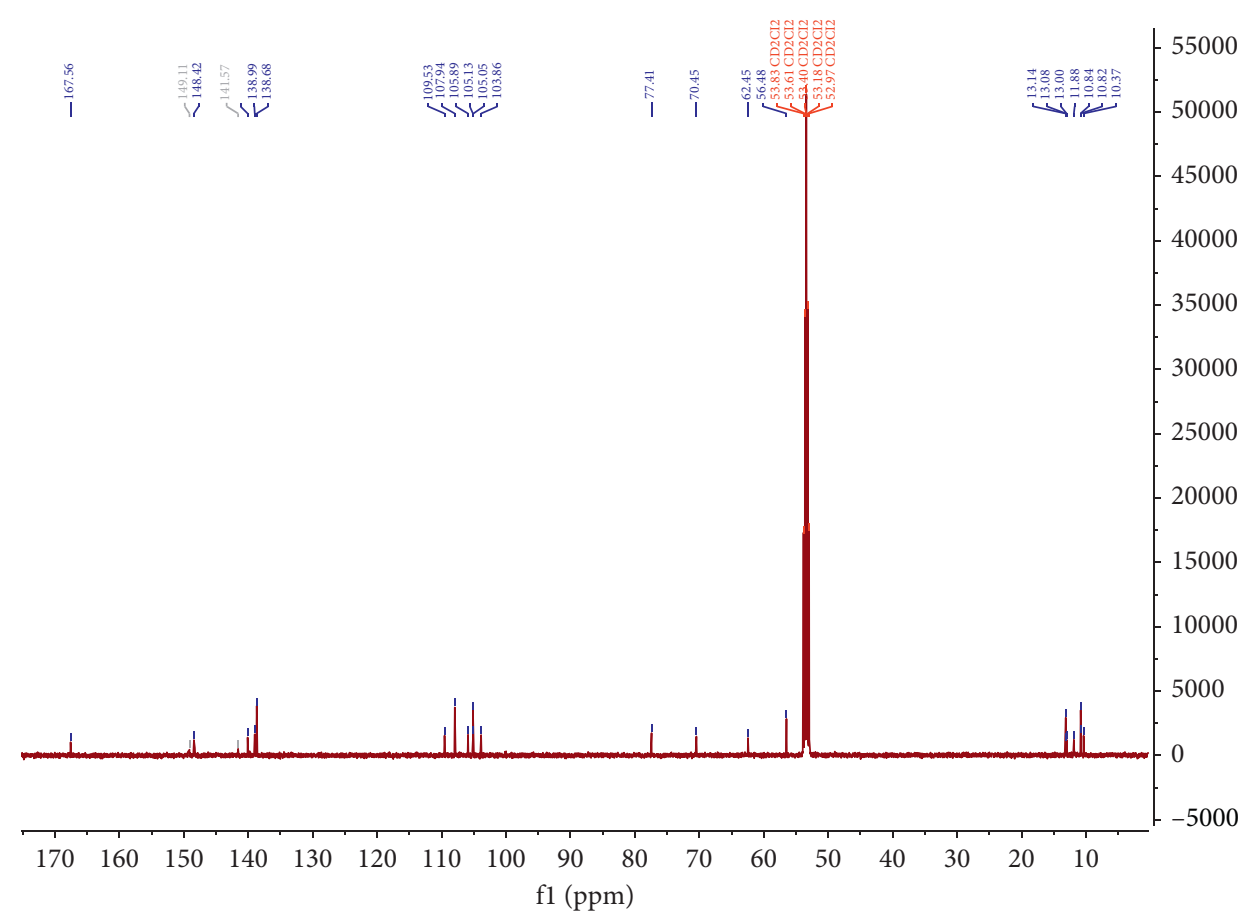

Figure 4: ${ }^{13} \mathrm{C}$ NMR spectrum $\mathrm{N}_{2}, \mathrm{~N}_{2}, \mathrm{~N}_{3}, \mathrm{~N}_{3}$-tetrakis((3,5-dimethyl-1H-pyrazol-1-yl)methyl)pyridine-2,3-diamine (13).

TABLe 1: Antibacterial activity of the newly synthesized mono- and tetra-alkylated pyrazole and triazole derivatives determined by the broth macrodilution assay and using the phenol red indicator.

\begin{tabular}{lcccc}
\hline Entry & L. monocytogenes & E. coli & S. aureus & C. freundii \\
\hline $\mathbf{1}$ & --- & --- & --- & --- \\
$\mathbf{2}$ & --- & --- & --- & --- \\
$\mathbf{3}$ & --- & --- & --- & --- \\
$\mathbf{4}$ & --- & --- & --- & --- \\
$\mathbf{5}$ & --- & --- & --- & --- \\
$\mathbf{6}$ & --- & --- & --- & --- \\
$\mathbf{7}$ & --- & --- & --- & --- \\
$\mathbf{8}$ & --- & --- & --- & --- \\
$\mathbf{9}$ & --- & --- & --- & --- \\
$\mathbf{1 0}$ & --- & --- & --- & --- \\
$\mathbf{1 1}$ & --- & --- & --- & --- \\
$\mathbf{1 2}$ & +++ & +++ & +++ & +++ \\
$\mathbf{1 3}$ & +++ & +++ & +++ & +++ \\
\hline
\end{tabular}

$\mathrm{MBC}=500 \mu \mathrm{M})$, and then L. monocytogenes $(\mathrm{MIC}=500 \mu \mathrm{M}$, $\mathrm{MBC}=800 \mu \mathrm{M})$.

All the prepared compounds were screened for their antifungal activity against two fungal strains, namely, Candida glabrata and Saccharomyces cerevisiae as described in Section 2.2.4. All the mono- and tetradentate pyrazole ligands tested (1-13) showed no antifungal activity against Candida glabrata. Figure 5 shows the result obtained with monodentate pyrazole ligands $\mathbf{9}, \mathbf{1 0}$, and $\mathbf{1 1}$ and tetradentate ones 12 and 13. In contrast, while monodentate pyrazole ligands were not toxic to Saccharomyces cerevisiae, tetradentate pyrazole ligands $\mathbf{1 2}$ and $\mathbf{1 3}$ exhibited significant antifungal activity against this strain (Figure 5). Interestingly, compound $\mathbf{1 2}$ showed stronger antifungal activity
TABLe 2: MIC (in $\mu \mathrm{M}$ ) and MBC (in $\mu \mathrm{M}$ ) values of active compounds 12 and 13 against the bacterial strains L. monocytogenes, E. coli, S. aureus, and C. freundii.

\begin{tabular}{|c|c|c|c|c|c|}
\hline Entry & & L. monocytogenes & E. coli & S. aureus & C. freundii \\
\hline \multirow{3}{*}{12} & MIC & 300 & 300 & 300 & 100 \\
\hline & $\mathrm{MBC}$ & 300 & 300 & 300 & 200 \\
\hline & $\begin{array}{c}\mathrm{MBC} / \\
\mathrm{MIC}\end{array}$ & 1 & 1 & 1 & 2 \\
\hline \multirow{3}{*}{13} & MIC & 500 & 500 & 400 & 300 \\
\hline & MBC & 800 & 500 & 500 & 400 \\
\hline & $\begin{array}{c}\mathrm{MBC} / \\
\mathrm{MIC}\end{array}$ & 1.6 & 1 & 1.25 & 1.3 \\
\hline
\end{tabular}

against Saccharomyces cerevisiae cells than compound $\mathbf{1 3}$ (Figure 5), consistent with their antibacterial activities demonstrated above.

Together, these results suggest that tetra-alkylated ligands 12 and 13 act as weak antifungal agents, but strong antibacterial agents, and might represent promising lead compounds for the development of specific antibacterial drugs. Therefore, further investigation is required to better understand their antibacterial activity and their mode of action. Thus, theoretical investigations such as SAR, ADMETox, and molecular docking were performed.

3.3. SAR Analysis of Compounds 12 and 13. The structure activity relationship (SAR) analysis of the tetra-alkylated pyrazole and triazole derivatives $\mathbf{1 2}$ and $\mathbf{1 3}$ revealed that the antibacterial activity of these compounds depends essentially on the nature of the starting materials (the diamine) which is benzene-1,3-diamine for compound $\mathbf{1 2}$ and pyridine-2,3- 


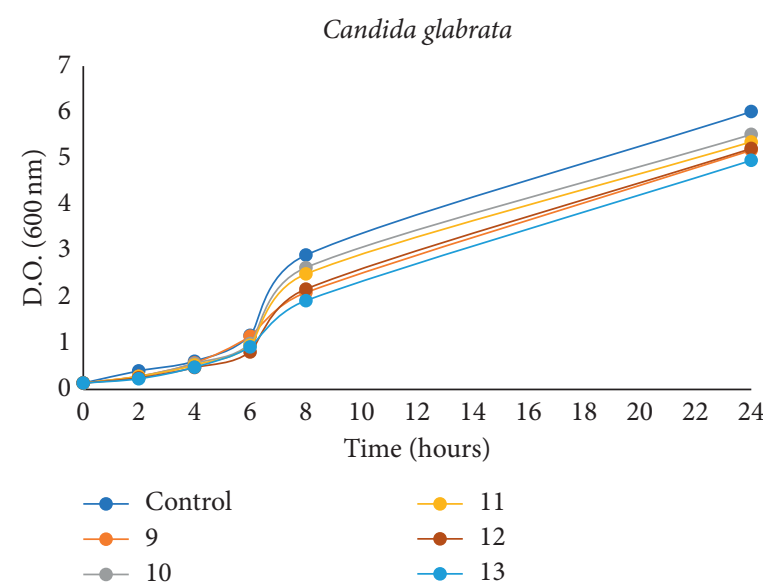

(a)

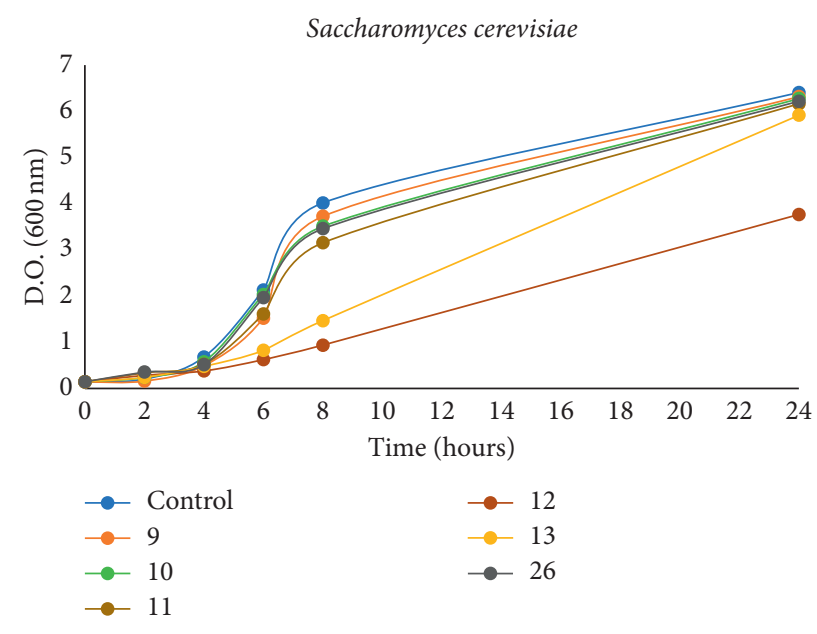

(b)

FIGURE 5: Activity of mono- and tetradentate pyrazole ligands against Candida glabrata and Saccharomyces cerevisiae. Cells were cultured in the absence ("no drug" control) or in the presence of $500 \mu \mathrm{M}$ of compounds 9-13.

diamine for compound 13. Investigation of $(R)$ substituents, showed that the presence of methyl makes compounds $\mathbf{1 2}$ and $\mathbf{1 3}$ active against Listeria monocytogenes, and also, the presence of the pyridine ring instead of benzene one and the positions of the amines on the starting material increase the $\mathrm{MBC} / \mathrm{MIC}$ ratio from 1 to 1.6 (Table 2). In the case of E. coli, $\mathrm{MBC} / \mathrm{MIC}$ is equal to 1 for the two compounds either they have different structure resulting in their inhibition mechanism of action on the bacteria. Otherwise, compound $\mathbf{1 3}$ shows a higher MBC/MIC ratio of 1.25 against Staphylococcus aureus which is probably due to the presence of the nitrogen of the pyridine rings in addition to the effect of the methyl substituents on the pyrazole rings and the difference of the diamine starting material.

3.4. DFT Study. MEP surfaces: molecular electrostatic potential (MEP) gives information about the reactive regions of nucleophilic and electrophilic attacks on a molecular system. It is often generated by mapping the electrostatic potential on the isoelectron density surface of the molecule, which gives us the opportunity to show the distribution of the electronic charge over all the structure. Currently, this technique becomes a useful tool to understand the molecule environment and the hydrogen bond interactions, as well as the biological recognition processes. Figure 6 shows the MEP surfaces generated by the DFT optimized geometries for compounds $\mathbf{1 2}$ and $\mathbf{1 3}$ that displayed strong antibacterial activity.

In this study, the MEP surfaces of compounds 12 and $\mathbf{1 3}$ showed negative charges located on $\mathrm{sp}^{2}$-nitrogen regions of the pyrazole ring with values of -1.1690 and $-1.4598 \mathrm{eV}$, respectively. Moreover, compound $\mathbf{1 2}$ showed another negative charge around the phenyl ring with a value of $-0.7042 \mathrm{eV}$, while compound $\mathbf{1 3}$ has another one around the $\mathrm{sp}^{3}$-nitrogen with value of $-1.1488 \mathrm{eV}$. In contrast, the positive charges were located on the methyl substituents on the pyrazole rings with a value of 2.1137 and $0.4522 \mathrm{eV}$, respectively. Therefore, both compounds have the same charge locations but difference in their values which is due to the condensed geometry of compound $\mathbf{1 3}$ that makes it more polarizable than compound $\mathbf{1 2}$.

3.5. ADME-Tox Predictions. The in silico predictions of the physicochemical properties such as ADME (absorption, distribution, metabolism, and excretion) and toxicity risks (Tox) are important in the drug discovery process [27]. It can predict the nature of a studied compound within the human body. Therefore, in the present work, swissADME web tool is used to check the ADME-Tox properties of the most active compounds $\mathbf{1 2}$ and $\mathbf{1 3}$ as well as streptomycin. The results are collected in Tables 3 and 4 .

Overall, excepting the molecular weight which is found to be higher than 500 daltons, the two compounds $\mathbf{1 2}$ and $\mathbf{1 3}$ displayed good ADME profiles and were found to follow the Lipinski rule of five for drug likeness in terms of their $\log \mathrm{P}$ $(<5)$, H-donor $(<5)$, H-acceptor $(<10)$, nrotb $(<10)$, and TPSA $\left(<140 \AA^{2}\right)$. These compounds were found to display better ADME profiles compared to streptomycin which showed more violations for the Lipinski rules.

On the other hand, the toxicity prediction reveals the nonmutagenic, nontumorigenic, and nonirritant proprieties and none risk on the reproductivity of compounds $\mathbf{1 2}$ and 13, whereas it showed a high irritant effect of streptomycin.

3.6. Molecular Docking Study. The two compounds $\mathbf{1 2}$ and 13 were docked with the active site of L-methionine $\gamma$-lyase enzyme (MGL) to generate their binding mode. After docking, it was found that both of the selected ligands can bind to the receptor residues via two types of interactions: $\pi-\mathrm{H}$ (in violet) and Van der Waals (in orange) interactions (Figure 7). Compound $\mathbf{1 2}$ was found to involve via the pyrazole rings in two $\pi$ - $\mathrm{H}$ interactions with $\mathrm{Thr} 354$ and Arg374 amino acids with distances of 2.79 and $3.67 \AA$, respectively, and via carbon atoms in three Van der Waals 


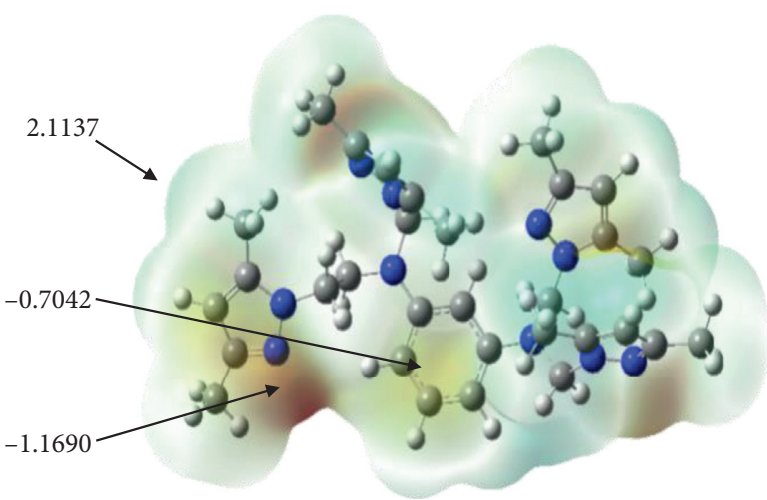

(a)

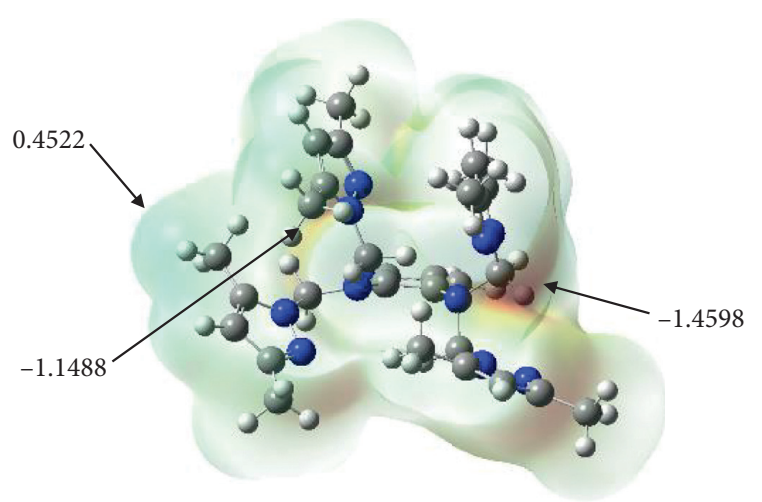

(b)

FIGURE 6: MEP surfaces presentation for the compounds 12 (a) and 13 (b).

TABle 3: Physicochemical properties of the most potent antibacterial pyrazole derivatives and the antibiotic control streptomycin.

\begin{tabular}{|c|c|c|c|c|c|c|}
\hline \multirow{2}{*}{ Entry } & \multicolumn{6}{|c|}{ Physicochemical properties } \\
\hline & MW & $\log P$ & H-don & $\mathrm{H}$-acc & nrotb & TPSA $\left(\AA^{2}\right)$ \\
\hline 12 & 540.71 & 4.87 & 0 & 4 & 10 & 77.76 \\
\hline 13 & 541.69 & 4.25 & 0 & 5 & 10 & 90.65 \\
\hline Streptomycin & 581.578 & -6.65 & 14 & 15 & 11 & 331.43 \\
\hline
\end{tabular}

MW: molecular weight expressed in daltons. Log P: octanol/water partition coefficient characterizing lipophilicity. H-don: number of hydrogen bond donors. $\mathrm{H}$-acc: number of hydrogen bond acceptors. nrotb: number of rotable bonds. TPSA: total polar surface area.

TABLE 4: Toxicity risks of the most potent antibacterial pyrazole derivatives and streptomycin.

\begin{tabular}{|c|c|c|c|c|}
\hline \multirow{2}{*}{ Entry } & \multicolumn{4}{|c|}{ Toxicity } \\
\hline & Mutagenic & Tumorigenic & Reproductivity & Irritant \\
\hline 12 & None & None & None & None \\
\hline 13 & None & None & None & None \\
\hline Streptomycin & None & None & None & High \\
\hline
\end{tabular}

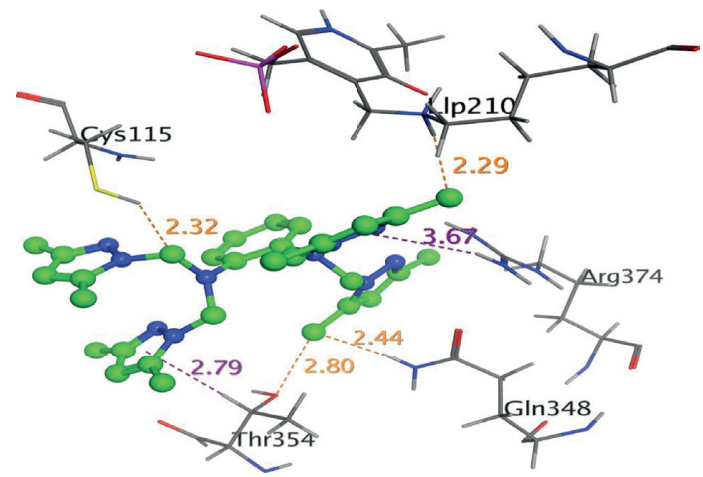

(a)

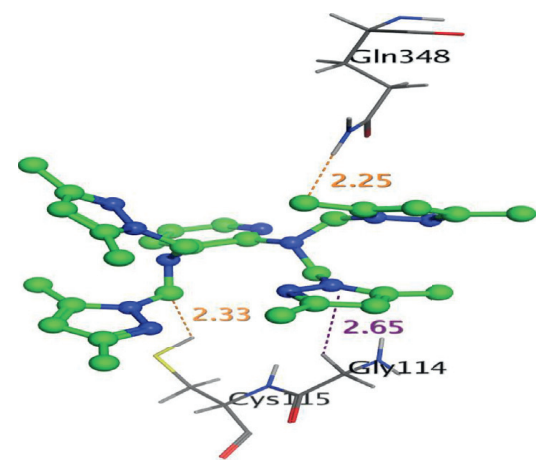

(b)

FiguRE 7: Interaction network of compound 12 (a) and compound 13 (b) with L-methionine $\gamma$-lyase enzyme residues.

interactions with Llp210, Gln348, and Thr354 residues. However, the study reveals that compound $\mathbf{1 3}$ has formed only one $\pi$-H interaction with Gly114 (2.65 $\AA$ ) residue and two Van der Waals interactions with Gln348 and Cys115 residues (2.25 and $2.33 \AA$, respectively). Apart from this, previous works $[28,29]$ demonstrated that some of the amino acids located in the binding pocket of MGL are very essential for the catalytic reaction of this enzyme such as cysteine (Cys) and arginine (Arg), a fact that allows us to suggest that our compounds can probably be potential leads to block the MGL action which can lead to the inhibition of the bacteria. 
TABle 5: Score, interactions, and bond length obtained for compounds 12 and 13 with MGL enzyme.

\begin{tabular}{|c|c|c|c|}
\hline Entry & $\begin{array}{c}\Delta \mathrm{G}_{\text {binding }} \text { in } \\
\mathrm{kcal} / \mathrm{mol}\end{array}$ & Interactions & Bond length $(\AA)$ \\
\hline 12 & -0.86 & $\begin{array}{c}\mathrm{CH}_{3}-\mathrm{H}(\mathrm{Llp} 210) \\
\mathrm{C}(\mathrm{N}-\mathrm{C}-\mathrm{N})- \\
\mathrm{H}(\mathrm{Cys} 115) \\
\mathrm{CH}_{3}-\mathrm{H}(\mathrm{Gln} 348) \\
\text { 5-ring-H(Thr354) } \\
\mathrm{CH}_{3}-\mathrm{O}(\mathrm{Thr} 354) \\
\text { 5-ring-H(Arg374) }\end{array}$ & $\begin{array}{l}2.29 \\
2.32 \\
2.44 \\
2.79 \\
2.80 \\
3.67\end{array}$ \\
\hline 13 & -6.71 & $\begin{array}{c}\left.\mathrm{CH}_{3}-\mathrm{H}(\mathrm{Gln} 348)\right) \\
\mathrm{C}(\mathrm{N}-\mathrm{C}-\mathrm{N})- \\
\mathrm{H}(\mathrm{Cys} 115) \\
\text { 5-ring-H(Gly114) }\end{array}$ & $\begin{array}{l}2.25 \\
2.33 \\
2.65\end{array}$ \\
\hline
\end{tabular}

The binding scores $\left(\Delta \mathrm{G}_{\text {binding }}\right)$ were also analyzed to measure the affinity of the selected ligands for the receptor. The most negative value of $\Delta \mathrm{G}_{\text {binding }}$ corresponds to the best binding pose of the protein-ligand complex, giving an insight about the most active compound. From the results displayed in Table 5, compound $\mathbf{1 2}$ was found to be associated with the highest binding energy value $(-6.86 \mathrm{kcal} /$ mol) compared to compound $\mathbf{1 3}$ which showed a $\Delta G_{\text {binding }}$ value of $-6.71 \mathrm{kcal} / \mathrm{mol}$. In the light of these outcomes, compound 12 seems more active than compound 13, which is in good agreement with the experimental antibacterial findings.

Overall, these docking results revealed clearly that the interaction between ligand 12 and MGL is higher and stronger $\left(\Delta \mathrm{G}_{\text {binding }}=-6.86 \mathrm{kcal} / \mathrm{mol}\right)$ than that between compound 13 and $\mathrm{MGL}\left(\Delta \mathrm{G}_{\text {binding }}=-6.71 \mathrm{kcal} / \mathrm{mol}\right)$, suggesting it as a potential MGL inhibitor. However, more computational calculations and suitable experimental investigations are required to confirm these good outcomes.

\section{Conclusions}

From thirteen heterocyclic compounds, only the two tetra$\mathrm{N}$-alkylated heterocyclic compounds (12 and 13) have excellent antimicrobial activities especially against $C$. freundii, with no antifungal activity. Furthermore, based on MEP and SAR analysis, the presence of the pyridine ring as a core with close pyrazole rings (closed cavity between the pyrazole rings) where the negative charges are located makes compound $\mathbf{1 3}$ more polarizable and best bactericidal candidate against Citrobacter freundii with close activity against studied bacterial strains. Otherwise, our compounds were found to display better ADME profile than streptomycin, and they showed no toxicity risks. The ligand protein docking study against L-methionine $\gamma$-lyase enzyme (MGL) in the case of $C$. freundii strain implies that compound $\mathbf{1 2}$ has a better affinity (more active) to the selected receptor than compound $\mathbf{1 3}$ which is in good accordance with the experimental antibacterial results. Further experimental studies are needed as perspectives to verify their MGL inhibition activity.

\section{Data Availability}

The data used to support the findings of this study are included within the article and also in Supplementary Materials.

\section{Conflicts of Interest}

The authors declare that there are no conflicts of interest regarding the publication of this paper.

\section{Authors' Contributions}

Y. Kaddouri and B. Bouchal contributed equally to this work where Y. Kaddouri conceived and designed the chemistry experiments, performed the theoretical investigations and experiments such as DFT and molecular docking, interpreted all the data, and wrote the paper. B. Bouchal performed the biological assays, collected the data, and revised the paper. M. Bellaoui conceived, designed the biological experiments, and revised the paper. F. Abrigach revised the paper and verified the docking study. M. El Kodadi and R. Touzani verified the chemistry part and revised the manuscript.

\section{Acknowledgments}

M. Bellaoui would like to thank the MESRSFC (Ministère de l'Enseignement Supérieur, de la Recherche Scientifique et de la Formation des Cadres) and the CNRST (Center National pour la Recherche Scientifique et Technique) for their support.

\section{Supplementary Materials}

Figure S1: ${ }^{1} \mathrm{H}$ NMR spectrum of N-((3,5-dimethyl-1Hpyrazol-1-yl)methyl)pyridin-2-amine (1). Figure $\mathrm{S} 2:{ }^{13} \mathrm{C}$ NMR spectrum of $\mathrm{N}-((3,5$-dimethyl-1H-pyrazol-1-yl) methyl)pyridin-2-amine (1). Figure S3: GC-MS spectrum of $\mathrm{N}$-((3,5-dimethyl-1H-pyrazol-1-yl)methyl)pyridin-2-amine (1). Figure S4: ${ }^{1} \mathrm{H}$ NMR spectrum of $\mathrm{N}-((3,5$-dimethyl- $1 \mathrm{H}-$ pyrazol-1-yl)methyl)-6-methylpyridin-2-amine (2). Figure S5: ${ }^{13} \mathrm{C}$ NMR spectrum of N-((3,5-dimethyl-1H-pyrazol-1yl)methyl)-6-methylpyridin-2-amine (2). Figure S6: GC-MS spectrum of $\mathrm{N}$-((3,5-dimethyl-1H-pyrazol-1-yl)methyl)-6methylpyridin-2-amine (2). Figure S7: ${ }^{1} \mathrm{H}$ NMR spectrum of $\mathrm{N}$-((1H-1,2,4-triazol-1-yl)methyl)-5-bromopyridin-2-amine (3). Figure S8: ${ }^{13} \mathrm{C}$ NMR spectrum of N-((1H-1,2,4-triazol-1yl)methyl)-5-bromopyridin-2-amine (3). Figure S9: GC-MS spectrum of $\mathrm{N}$-((1H-1,2,4-triazol-1-yl)methyl)-5-bromopyridin-2-amine (3). Figure S10: ${ }^{1} \mathrm{H}$ NMR spectrum of $\mathrm{N}$-((1H-pyrazol-1-yl)methyl)-5-bromopyridin-2-amine (4). Figure S11: ${ }^{13} \mathrm{C}$ NMR spectrum of $\mathrm{N}-((1 \mathrm{H}-$ pyrazol-1-yl $)$ methyl)-5-bromopyridin-2-amine (4). Figure S12: GC-MS spectrum of N-((1H-pyrazol-1-yl)methyl)-5-bromopyridin2-amine (4). Figure S13: ${ }^{1} \mathrm{H}$ NMR spectrum of 5-bromo-N((3,5-dimethyl-1H-pyrazol-1-yl)methyl)pyridin-2-amine (5). Figure S14: ${ }^{13} \mathrm{C}$ NMR spectrum of 5-bromo-N-((3,5dimethyl-1H-pyrazol-1-yl)methyl)pyridin-2-amine (5). Figure S15: GC-MS spectrum of 5-bromo-N-((3,5-dimethyl- 
1H-pyrazol-1-yl)methyl)pyridin-2-amine (5). Figure S16: ${ }^{1} \mathrm{H}$ NMR spectrum of $\mathrm{N}-((1 \mathrm{H}-$ pyrazol-1-yl)methyl)thiazol2 -amine (6). Figure S17: ${ }^{13} \mathrm{C}$ NMR spectrum of $\mathrm{N}-((1 \mathrm{H}-$ pyrazol-1-yl)methyl)thiazol-2-amine (6). Figure S18: GCMS spectrum of $\mathrm{N}-((1 \mathrm{H}-$ pyrazol-1-yl)methyl)thiazol-2amine (6). Figure S19: ${ }^{1} \mathrm{H}$ NMR spectrum of $\mathrm{N}-((3,5-\mathrm{di}-$ methyl-1H-pyrazol-1-yl)methyl)thiazol-2-amine (7). Figure S20: ${ }^{13} \mathrm{C}$ NMR spectrum of $\mathrm{N}-((3,5$-dimethyl-1H-pyrazol-1yl)methyl)thiazol-2-amine (7). Figure S21: GC-MS spectrum of $\quad \mathrm{N}-((3,5-$ dimethyl-1H-pyrazol-1-yl)methyl)thiazol-2amine (7). Figure S22: ${ }^{1} \mathrm{H}$ NMR spectrum of N-((3,5-dimethyl-1H-pyrazol-1-yl)methyl)pyridin-4-amine (8). Figure S23: ${ }^{13} \mathrm{C}$ NMR spectrum of $\mathrm{N}-((3,5-$ dimethyl- $1 \mathrm{H}-$ pyrazol-1-yl)methyl)pyridin-4-amine (8). Figure S24: $\mathrm{N}$-((3,5-dimethyl-1H-pyrazol-1-yl)methyl)pyridin-4-amine (8). Figure S25: ${ }^{1} \mathrm{H}$ NMR spectrum of ethyl $1-((1 \mathrm{H}$-imidazol1-yl)methyl)-5-methyl-1H-pyrazole-3-carboxylate (9). Figure S26: ${ }^{13} \mathrm{C}$ NMR spectrum of ethyl 1-((1H-imidazol-1-yl) methyl)-5-methyl-1H-pyrazole-3-carboxylate (9). Figure S27: GC-MS spectrum of ethyl 1-((1H-imidazol-1-yl) methyl)-5-methyl-1H-pyrazole-3-carboxylate (9). Figure S28: ${ }^{1} \mathrm{H}$ NMR spectrum of 2-(((1H-pyrazol-1-yl)methyl) amino)-6-methylpyridin-4-ol (10). Figure S29: ${ }^{13} \mathrm{C}$ NMR spectrum of 2-(((1H-pyrazol-1-yl)methyl)amino)-6-methylpyridin-4-ol (10). Figure S30: GC-MS spectrum of 2(((1H-pyrazol-1-yl) methyl)amino)-6-methylpyridin-4-ol (10). Figure S31: ${ }^{1} \mathrm{H}$ NMR spectrum of 2-(((3,5-dimethyl1H-pyrazol-1-yl)methyl)amino)-6-methylpyridin-4-ol (11). Figure S32: ${ }^{13} \mathrm{C}$ NMR spectrum of 2-(( (3,5-dimethyl-1Hpyrazol-1-yl)methyl)amino)-6-methylpyridin-4-ol (11). Figure S33: GC-MS spectrum of 2-(( 3,5 -dimethyl-1Hpyrazol-1-yl)methyl)amino)-6-methylpyridin-4-ol (11). Figure S34: ${ }^{1} \mathrm{H}$ NMR spectrum of $\mathrm{N}_{1}, \mathrm{~N}_{1}, \mathrm{~N}_{3}, \mathrm{~N}_{3}$-tetrakis((3,5dimethyl-1H-pyrazol-1-yl)methyl)benzene-1,3-diamine (12). Figure S35: ${ }^{13} \mathrm{C}$ NMR of $\mathrm{N}_{1}, \mathrm{~N}_{1}, \mathrm{~N}_{3}, \mathrm{~N}_{3}$-tetrakis $((3,5$ dimethyl-1H-pyrazol-1-yl)methyl)benzene-1,3-diamine (12). Figure S36: ${ }^{1} \mathrm{H}$ NMR spectrum $\mathrm{N}_{2}, \mathrm{~N}_{2}, \mathrm{~N}_{3}, \mathrm{~N}_{3}$-tetrakis((3,5-dimethyl-1H-pyrazol-1-yl)methyl)pyridine-2,3-diamine (13). Figure S37: ${ }^{13} \mathrm{C}$ NMR spectrum $\mathrm{N}_{2}, \mathrm{~N}_{2}, \mathrm{~N}_{3}, \mathrm{~N}_{3}-$ tetrakis((3,5-dimethyl-1H-pyrazol-1-yl)methyl)pyridine2,3-diamine (13). (Supplementary Materials)

\section{References}

[1] L. Rao, R. Tian, and X. Chen, "Cell-membrane-mimicking nanodecoys against infectious diseases," ACS Nano, vol. 14, no. 3, pp. 2569-2574, 2020.

[2] A. Lauria, R. Delisi, F. Mingoia et al., "1,2,3-Triazole in heterocyclic compounds, endowed with biological activity, through 1,3-dipolar cycloadditions," European Journal of Organic Chemistry, vol. 2014, no. 16, pp. 3289-3306, 2014.

[3] E. Jimnez, A. Hodder, and A. Oihabi, "FAO support to date palm development around the world: 70 years of activity," Emirates Journal of Food and Agriculture, vol. 28, no. 1, p. 1, 2016.

[4] S. L. Lima, A. L. Colombo, and J. N. de Almeida Junior, "Fungal cell wall: emerging antifungals and drug resistance," Frontiers in Microbiology, vol. 10, p. 2573, 2019.
[5] G. Wall and J. L. Lopez-Ribot, "Current antimycotics, new prospects, and future approaches to antifungal therapy," Antibiotics, vol. 9, no. 8, p. 445, 2020.

[6] J. Pizarro-Cerda, A. Kuhbacher, and P. Cossart, "Entry of Listeria monocytogenes in mammalian epithelial cells: an updated view," Cold Spring Harbor Perspectives in Medicine, vol. 2, no. 11, Article ID a010009, 2012.

[7] B. Lungu, C. A. O'Bryan, A. Muthaiyan et al., "Listeria monocytogenes: antibiotic resistance in food production," Foodborne Pathogens and Disease, vol. 8, no. 5, pp. 569-578, 2011.

[8] F. X. Riedo, R. W. Pinner, M. d. L. Tosca et al., "A point-source foodborne listeriosis outbreak: documented incubation period and possible mild illness," Journal of Infectious Diseases, vol. 170, no. 3, pp. 693-696, 1994.

[9] T. J. Montville, K. R. Matthews, and K. E. Kniel, Food Microbiology: An Introduction, ASM Press, Washington, NJ, USA, 2012.

[10] M. Thakur, R. K. Asrani, and V. Patial, "Listeria monocytogenes: a food-borne pathogen in," Foodborne Diseases Handbook of Food Bioengineering, Elsevier, Amsterdam, Netherlands, pp. 157-192, 2018.

[11] S. Y. C. Tong, J. S. Davis, E. Eichenberger, T. L. Holland, and V. G. Fowler Jr., "Staphylococcus aureus infections: epidemiology, pathophysiology, clinical manifestations, and management," Clinical Microbiology Reviews, vol. 28, no. 3, pp. 603-661, 2015.

[12] S. Makvana and L. R. Krilov, "Escherichia coli infections," Pediatrics in Review, vol. 36, no. 4, pp. 167-171, 2015.

[13] L.-H. Liu, N.-Y. Wang, A. Y.-J. Wu, C.-C. Lin, C.-M. Lee, and C.-P. Liu, "Citrobacter freundii bacteremia: risk factors of mortality and prevalence of resistance genes," Journal of Microbiology, Immunology and Infection, vol. 51, no. 4, pp. 565-572, 2018.

[14] P. Munoz, E. Bouza, M. Cuenca-Estrella et al., "Saccharomyces cerevisiae fungemia: an emerging infectious disease," Clinical Infectious Diseases, vol. 40, no. 11, pp. 1625-1634, 2005.

[15] M. A. Kabir, M. A. Hussain, and Z. Ahmad, "Candida albicans: a model organism for studying fungal pathogens," ISRN Microbiology, vol. 2012, Article ID 538694, 15 pages, 2012.

[16] S. J. P. A. L. Saiman, "Antibiotic resistance in neonatal intensive care unit pathogens: mechanisms, clinical impact and prevention including antibiotic stewardship," Clinics in Perinatology, vol. 37, no. 3, pp. 547-563, 2010.

[17] N. Arrousse, R. Salim, Y. Kaddouri et al., "The inhibition behavior of two pyrimidine-pyrazole derivatives against corrosion in hydrochloric solution: experimental, surface analysis and in silico approach studies," Arabian Journal of Chemistry, vol. 13, no. 7, pp. 5949-5965, 2020.

[18] Y. Kaddouri, F. Abrigach, N. Mechbal et al., "Pyrazole Compounds : synthesis, molecular structure, chemical reactivity, experimental and theoretical DFT FTIR spectra," Materials Today: Proceedings, vol. 13, pp. 956-963, 2019.

[19] Y. Kaddouri, F. Abrigach, E. B. Yousfi, M. El Kodadi, and R. Touzani, "New thiazole, pyridine and pyrazole derivatives as antioxidant candidates: synthesis, DFT calculations and molecular docking study," Heliyon, vol. 6, no. 1, Article ID e03185, 2020.

[20] Y. Kaddouri, A. Takfaoui, F. Abrigach et al., "Tridentate pyrazole ligands: synthesis, characterization and corrosion inhibition properties with theoretical investigations," Journal of Materials and Environmental Science, vol. 8, no. 3, pp. 845-856, 2017. 
[21] A. T. Y. Kaddouri, F. Abrigach, M. El Azzouzi et al., "Tridentate pyrazole ligands: synthesis, characterization and corrosion inhibition properties with theoretical investigations," Journal of Materials and Environmental, vol. 8, no. 3, pp. 845-856, 2017.

[22] H. H. Y. Kaddouri, A. Titi, EB. Yousfi, A. Chetouani, M. El Kodadi, and R. Touzani, "Catecholase catalytic properties of copper (II) complexes prepared in-situ with heterocyclic ligands: experimental and DFT study," Moroccan Journal of Chemistry, vol. 8, no. 1, pp. 184-196, 2020.

[23] L. Biyiti, D. Meko'o, V. Tamzc, and P. Amvam Zollo, "Recherche de l'activité antibactérienne de quatre plantes médicinales camerounaises," Pharmaceutical Medicine of African Journal of Traditional, vol. 13, pp. 11-20, 2004.

[24] P. Berche, J. Gaillard, and M. Simonet, Les bactéries des infections humaines, Editeur Flammarion (Médecine et Sciences), Paris, France, 1991.

[25] J. Ennadir, R. Hassikou, F. Bouazza, M. Arahou, G. Al Askari, and K. Khedid, "Évaluation in vitro de l'activité antibactérienne des extraits aqueux et organiques des graines de Nigella sativa L. et de Foeniculum vulgare Mill," Phytothérapie, vol. 12, no. 5, pp. 302-308, 2014.

[26] M. Frisch, G. Trucks, H. Schlegel et al., GAUSSIAN09, Gaussian Inc., Wallingford, CT, USA, 2009.

[27] S. Alqahtani, "In silicoADME-Tox modeling: progress and prospects," Expert Opinion on Drug Metabolism \& Toxicology, vol. 13, no. 11, pp. 1147-1158, 2017.

[28] D. V. Mamaeva, E. A. Morozova, A. D. Nikulin et al., "Structure ofCitrobacter freundiiL-methionine $\gamma$-lyase," Acta Crystallographica Section F Structural Biology and Crystallization Communications, vol. 61, no. 6, pp. 546-549, 2005.

[29] D. Kudou, S. Misaki, M. Yamashita et al., "Structure of the antitumour enzyme L-methionine -lyase from Pseudomonas putida at 1.8 A resolution," Journal of Biochemistry, vol. 141, no. 4 , pp. 535-544, 2007. 